GRASAS Y ACEITES 67 (2)

April-June 2016, e137

ISSN-L: 0017-3495

doi: http://dx.doi.org/10.3989/gya.0764152

\title{
Olive paste oil content on a dry weight basis (OPDW): an indicator for optimal harvesting time in modern olive orchards
}

\author{
I. Zipori ${ }^{\mathrm{a}}$, A. Bustan ${ }^{\mathrm{b}}$, Z. Kerem ${ }^{\mathrm{c}}$ and A. Dag ${ }^{\mathrm{a}, \mathbb{}}$ \\ ${ }^{a}$ Gilat Research Center, Agricultural Research Organization, Ministry of Agriculture, Mobile Post Negev 85280, Israel \\ ${ }^{\mathrm{b}}$ Ramat Negev R\&D, Desert Agro-Research Center, D.N. Halutza 85515, Israel \\ ${ }^{\mathrm{c}}$ Institute of Biochemistry, Food Science and Nutrition, The Robert H. Smith Faculty of Agriculture, \\ Food and Environment, The Hebrew University of Jerusalem, P.O. Box 12, Rehovot 76100, Israel \\ ${ }^{凶}$ Corresponding author: arnondag@volcani.agri.gov.il
}

Submitted: 31 July 2015; Accepted: 22 December 2015

\begin{abstract}
SUMMARY: In modern oil olive orchards, mechanical harvesting technologies have significantly accelerated harvesting outputs, thereby allowing for careful planning of harvest timing. While optimizing harvest time may have profound effects on oil yield and quality, the necessary tools to precisely determine the best date are rather scarce. For instance, the commonly used indicator, the fruit ripening index, does not necessarily correlate with oil accumulation. Oil content per fruit fresh weight is strongly affected by fruit water content, making the ripening index an unreliable indicator. However, oil in the paste, calculated on a dry weight basis (OPDW), provides a reliable indication of oil accumulation in the fruit. In most cultivars tested here, OPDW never exceeded ca. $0.5 \mathrm{~g} \cdot \mathrm{g}^{-1}$ dry weight, making this threshold the best indicator for the completion of oil accumulation and its consequent reduction in quality thereafter. The rates of OPDW and changes in quality parameters strongly depend on local conditions, such as climate, tree water status and fruit load. We therefore propose a fast and easy method to determine and monitor the OPDW in a given orchard. The proposed method is a useful tool for the determination of optimal harvest timing, particularly in large plots under intensive cultivation practices, with the aim of increasing orchard revenues.
\end{abstract}

The results of this research can be directly applied in olive orchards, especially in large-scale operations. By following the proposed method, individual plots can be harvested according to sharp thresholds of oil accumulation status and pre-determined oil quality parameters, thus effectively exploiting the potentials of oil yield and quality. The method can become a powerful tool for scheduling the harvest throughout the season, and at the same time forecasting the flow of olives to the olive mill.

KEYWORDS: Near infrared; Oil yield potential; Olea europaea L; Olive paste

RESUMEN: Contenido de aceite en pasta de aceituna sobre una base de peso seco (OPDW): un indicador del tiempo de cosecha óptimo en modernos olivares. En los modernos olivares, las tecnologías de recogida mecánica han acelerado significativamente la recogida de las cosechas, lo que permite la planificación del momento idóneo de la cosecha. Mientras que la optimización de tiempo de cosecha puede tener importantes efectos en la producción de un aceite de calidad, las herramientas para determinar con precisión la mejor fecha de la cosecha son más bien pobres. Por ejemplo, el indicador de uso común, el índice de maduración de la fruta, no se correlaciona necesariamente con la acumulación de aceite. El contenido de aceite por peso de fruto fresco está estrechamente afectado por el contenido de agua de la fruta, por lo que es un indicador poco fiable. Sin embargo, el aceite en la pasta, calculado sobre una base de peso seco (OPDW), proporciona una indicación fiable de la acumulación de aceite en el fruto. En la mayoría de los cultivares analizados aquí, OPDW nunca excedió $0.5 \mathrm{~g} \cdot \mathrm{g}^{-1}$ de peso seco, haciendo de este umbral 


\begin{abstract}
el mejor indicador para la terminación de la acumulación de aceite y su consiguiente reducción de la calidad. Las tasas de OPDW y los cambios en los parámetros de calidad dependen en gran medida de las condiciones locales, como el clima, el estado hídrico del árbol, y la carga frutal. Por tanto, proponemos un método rápido y fácil de determinar y seguir OPDW en un olivar determinado. El método propuesto es una herramienta útil para la determinación del momento óptimo de cosecha, especialmente en las grandes parcelas bajo prácticas intensivas de cultivo, y con el consiguiente aumento de ingresos. Los resultados de esta investigación pueden aplicarse directamente a un olivar, especialmente en operaciones a gran escala. Siguiendo el método propuesto, las parcelas individuales pueden cosecharse de acuerdo con los perfiles de estado de acumulación de aceite y determinados parámetros de calidad del aceite, por lo tanto explotar eficazmente los potenciales de rendimiento de aceite y calidad. El método puede convertirse en una poderosa herramienta de programar la cosecha a lo largo de la temporada, la previsión de este modo el flujo de las aceitunas a la almazara.
\end{abstract}

PALABRAS CLAVE: Infrarrojo cercano; Olea europea L.; Pasta de oliva; Potencial de rendimiento de aceite

Citation/Cómo citar este artículo: Zipori I, Bustan A, Kerem Z, Dag A. 2016. Olive paste oil content on a dry weight basis (OPDW): an indicator for optimal harvesting time in modern olive orchards. Grasas Aceites 67 (2): e137. doi: http://dx.doi.org/10.3989/gya.0764152.

Copyright: (C) 2016 CSIC. This is an open-access article distributed under the terms of the Creative Commons Attribution-Non Commercial (by-nc) Spain 3.0 Licence.

\section{INTRODUCTION}

Fruit harvesting is the most important activity in olive orchards. Traditionally, olive harvesting is performed manually or is semi-mechanized and as such, it is highly labor-intensive (García et al., 2010). The restricted availability of laborers forces an extended harvest period, even in small orchards. To collect the entire yield, harvesting usually begins quite early and ends very late in the season. In many cases, local traditions, fruit yield, topography and weather conditions are all pertinent parameters in determining harvest initiation. Other considerations that strongly affect the orchard revenue, such as yield and quality, are not under practical control in the traditional olive farm and are therefore neglected. A consequence of the common olive grower's poor ability to select an optimal harvesting time is the largely compromised quality of commercially produced olive oils (García et al., 1996).

The development of mechanized harvesting solutions for the growing proportion of intensive oil olive orchards has brought about an upsurge of harvesting output and speed. Ravetti and Robb (2010) reported an average speed of 108 tree/h at a cost of $1.39 € /$ tree for the mechanized harvesting of commercial olive trees in Australia, about 100 times faster than the average worker in a traditional olive farm. Lavee (2010) estimated a trunk-shaker system and overhead harvester to be 10 and 200 times faster than manual collection, respectively. Similar harvesting rates using trunk shakers were reported by Zion et al. (2011). Tous (2011) reported that straddle harvesters are twice as fast as trunk shakers with an inverted umbrella. Provided with such technologies, the opportunity for agriculturalists to harvest an orchard with precise timing has become feasible.

Harvesting time has a significant impact on oil yield and quality (Salvador et al., 2001; Beltrán et al., 2004;
Cherubini et al., 2009; Dag et al., 2011; Migliorini et al., 2011; Dag et al., 2013), the two major revenue determinants, particularly in the highly productive intensively cultivated olive orchards. The foremost goal of the olive grower is to optimize these two components by exploiting the complete potential for oil production at the desired level of oil quality. Are there suitable means which are accessible to growers to determine the optimal harvesting time in a given orchard and year?

In the present study, the common indicators that serve to select harvesting time are revisited, emphasizing their drawbacks and inadequacy for the modern olive oil industry. We propose a straightforward method to evaluate the oil yield potential at a given orchard on a given day. Once the oil yield potential approaches it maximum level, oil quality considerations will determine the appropriate harvesting time.

\section{MATERIALS AND METHODS}

\subsection{Plant material, locations, and schedule of experiments}

A series of 14 experiments, detailed in Table 1 , were conducted in the years 2005-2010 in four olive orchards in Israel: Revivim $\left(31^{\circ} 02^{\prime} 40.73^{\prime \prime} \mathrm{N}\right.$; $\left.34^{\circ} 43^{\prime} 15.90^{\prime \prime} \mathrm{E}\right)$, Kefar Menahem $\left(31^{\circ} 45^{\prime} 00.52^{\prime \prime} \mathrm{N}\right.$; $\left.34^{\circ} 51^{\prime} 04.51^{\prime \prime} \mathrm{E}\right)$, Gilat (31 $\left.33^{\prime} 50.91^{\prime \prime} \mathrm{N} ; 34^{\circ} 66^{\prime} 53.84^{\prime \prime} \mathrm{E}\right)$, and Ein Hanatziv (32 $\left.47^{\prime} 07.10^{\prime \prime} \mathrm{N} ; 35^{\circ} 50^{\prime} 19.97^{\prime \prime} \mathrm{E}\right)$. In each experiment, trees of uniform canopy size, trunk circumference and fruit load were selected in August, long before the beginning of the harvest season. For each pre-determined harvest date, five trees (replicates) were selected. The intervals between harvests were 2-3 weeks, from very early in the season (end of September/beginning of October) to the last harvest, which was determined according to the trees ${ }^{6}$ fruit load. 
Olive paste oil content on a dry weight basis (OPDW): an indicator for optimal harvesting time in modern olive orchards $\bullet 3$

TABLE 1. Location, cultivar, harvesting period, and fruit yield of 14 experiments performed in the years 2005-2011 in typical olive-growing regions in Israel

\begin{tabular}{|c|c|c|c|c|c|}
\hline \multirow[b]{2}{*}{ Harvest season } & \multirow[b]{2}{*}{ Location } & \multirow[b]{2}{*}{ Cultivar } & First harvest & Last harvest & \multirow{2}{*}{$\frac{\text { Fruit yield }}{\text { (kg/tree) }}$} \\
\hline & & & \multicolumn{2}{|c|}{ dd.mm.yy } & \\
\hline $2005 / 6$ & Revivim & Barnea & 02.10 .05 & 06.02 .06 & $75-80$ \\
\hline $2006 / 7$ & Revivim & Barnea & 08.10 .06 & 25.01 .07 & $70-80$ \\
\hline $2006 / 7$ & Revivim & Souri & 08.10 .06 & 11.01 .07 & $50-60$ \\
\hline $2007 / 8$ & Revivim & Picual & 16.10 .07 & 21.01 .08 & $45-50$ \\
\hline $2007 / 8$ & Revivim & Picual & 08.10 .07 & 18.11.07 & 30 \\
\hline $2007 / 8$ & Revivim & Souri & 08.10 .07 & 18.11 .07 & 30 \\
\hline $2008 / 9$ & KefarMenahem & Barnea & 25.09 .08 & 16.11 .08 & $30-40$ \\
\hline $2008 / 9$ & KefarMenahem & Souri & 19.10 .08 & 26.01 .09 & $70-80$ \\
\hline $2008 / 9$ & KefarMenahem & Koroneiki & 25.11 .08 & 18.02 .09 & 50 \\
\hline $2008 / 9$ & Gilat & Leccino & 25.09 .08 & 01.12 .08 & 30 \\
\hline $2009 / 10$ & EinHanatziv & Barnea & 20.10 .09 & 26.01 .10 & $65-75$ \\
\hline 2009/10 & EinHanatziv & Picual & 20.10 .09 & 26.01 .10 & $80-90$ \\
\hline 2010/11 & EinHanatziv & Barnea & 04.10 .10 & 10.01 .11 & $70-80$ \\
\hline $2010 / 11$ & EinHanatziv & Picual & 04.10 .10 & 10.01 .11 & $80-90$ \\
\hline
\end{tabular}

In 2011-2012, a countrywide survey comprising of 25 orchards (cv. Barnea) was carried out. In each orchard, the fruit yield of sampled trees was recorded and fruit samples were collected close to the commercial harvest time. A detailed description of the survey can be found in Bustan et al. (2014).

In 2012, 20 'Barnea' trees-10 high-yielding ('On', >40 kg/tree) and 10 low-yielding ('Off', $<20 \mathrm{~kg} /$ tree) - were selected in the orchard near Kefar Menahem (31 $\left.{ }^{\circ} 44^{\prime} 54.24^{\prime \prime} \mathrm{N} ; 34^{\circ} 51^{\prime} 10^{\prime \prime} \mathrm{E}\right)$. Fruit from both groups was sampled $(2 \mathrm{~kg})$ every 2 weeks, from 17 Oct. to 19 Dec.

\subsection{Fruit harvest and characterization}

Harvest was executed using electric combs (Olivium, Pellenc, France) that shed the fruit onto plastic nets. The yield was collected and weighed, and a representative $3 \mathrm{~kg}$ sample was taken for further analysis. In the laboratory, 100 fruits were randomly selected for a determination of average fruit weight and fruit ripening index (FRI), according to Uceda and Frias (1975).

\subsection{Oil extraction}

The oil was extracted using an Abencor laboratory mill (mc2, Ingenieria y sistemas, Seville, Spain). The system's operation was modified for olives originating from irrigated orchards according to Ben-David et al. (2010). A detailed description of the process was published by Dag et al. (2011). In the 2005/6-2007/8 seasons, total oil and water content in the olive paste were determined gravimetrically by means of Soxhlet extraction (Harwood and Moody, 1989).

\subsection{Calibration and validation of the near infrared (NIR) method for oil and water contents in olive paste}

In the 2008/9-2010/11 seasons, the oil and water contents were measured in each sample both gravimetrically (Soxhlet) and by using a near infrared (NIR) spectrometer (OliveScan ${ }^{\mathrm{TM}}$, Foss, Denmark). The NIR spectra obtained in 2008/9, together with the gravimetrically obtained data resulted in a data base of 978 samples that was used to improve the initial calibration of the OliveScan ${ }^{\mathrm{TM}}$. In 2009/10 and 2010/11, 1165 and 862 samples, respectively, were analyzed both gravimetrically and by NIR measurements and served as validation for the OliveScan ${ }^{\mathrm{TM}}$ calibration (Figure 1). The correlation between measured (Soxhlet) and predicted (NIR) results was very high, with a very small percentage of outliers, which could be attributed to either prediction (NIR) or laboratory measurement (Soxhlet) errors. The accuracy obtained using the NIR spectrometry with OliveScan ${ }^{\mathrm{TM}}$ has been recommended recently as sufficient for all practical purposes (Armenta et al., 2010). In the 2011 and 2012 seasons, the fruit oil and water contents were determined solely by the NIR technology.

\subsection{Determination of oil content per dry matter (OPDW)}

The oil content in the olive paste on a dry weight basis was calculated as:

OPDW=FWOC $/(100-W C)$;

Where OPDW represents the paste oil fraction on a dry weight basis, FWOC is the paste oil 

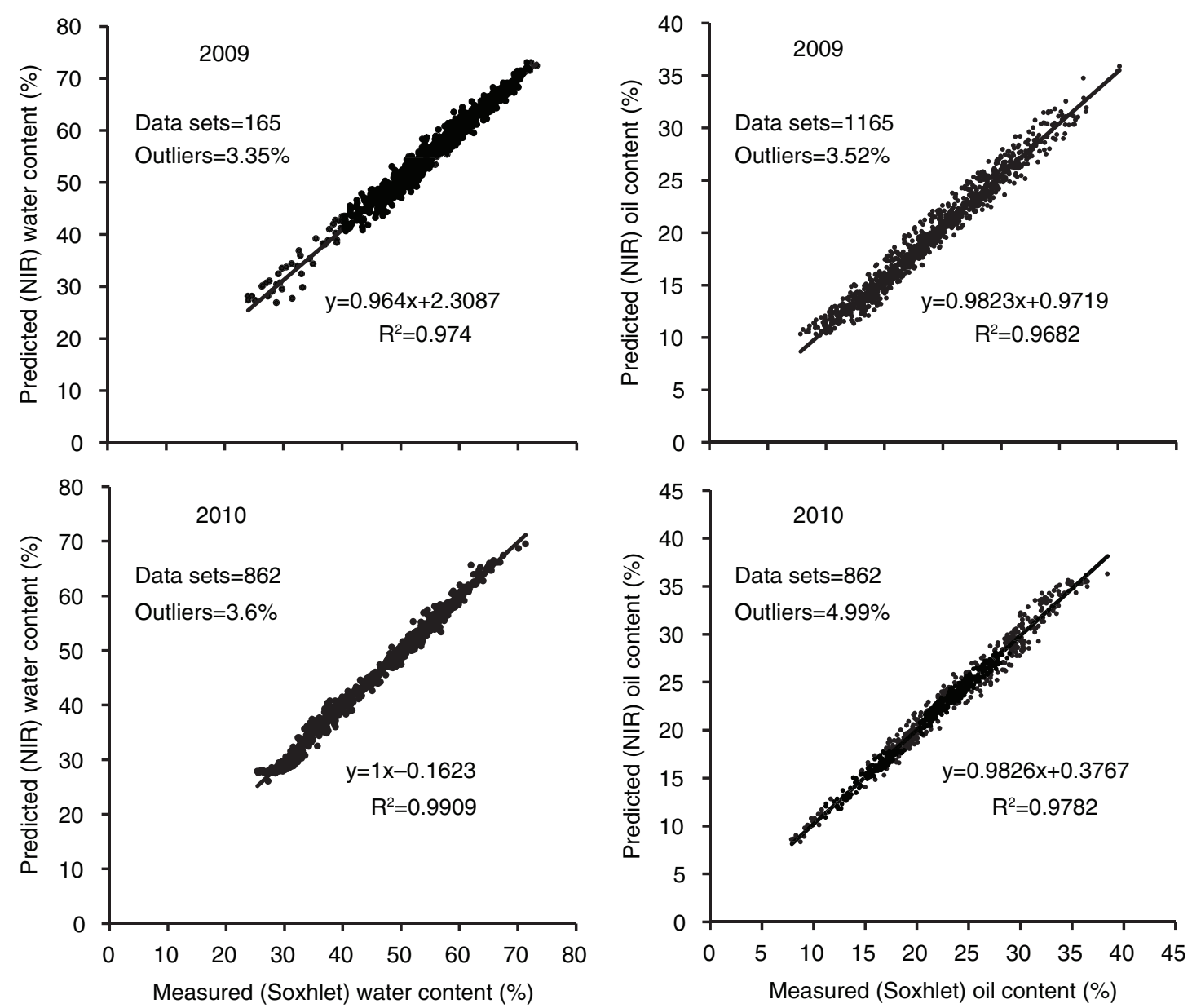

FIGURE 1. NIR (OliveScan ${ }^{\mathrm{TM}}$ ) predicted vs. Soxhlet measured validation data for water (left) and oil (right) contents in olive paste in 2009 and 2010.

content $(\%)$ on a fresh weight basis, and $\mathrm{WC}$ is the paste water content $(\%)$.

\subsection{Determination of oil acidity}

Oil acidity, in terms of free fatty acid (FFA) content, was determined following the analytical methods described in ISO 660 and Dag et al. (2011).

\section{RESULTS AND DISCUSSION}

The oil content in the paste, calculated on a fresh weight basis, would have been the first choice for determining oil yield at any point in time; it is a direct measurement of the fruit oil content, and employing recent technologies such as NIR spectrometry, rapidly produces reliable figures (García Sánchez et al., 2005; Cayuela et al., 2009; Naor et al., 2012; Armenta et al., 2015). In fact, fruit oil content on a fresh weight basis is the common parameter used by the industry to determine, after harvest, the actual oil yield at the press and the consequent reimbursement to the grower. Nevertheless, in terms of predicting the oil yield of a given orchard to determine optimal harvesting time, the oil content on a fresh weight basis seems to be somewhat unreliable, as it often fluctuates considerably due to environmental factors. Actually, fruit water content, a built-in parameter in the determination of oil content on a fresh weight basis, is very sensitive to the tree's contemporaneous water status. An unstable water supply due to either an improper irrigation regime or rainfall events may significantly and rapidly affect fruit water content (Proietti and Antognozzi, 1996). These fluctuations in fruit water content inversely modify the respective values of the oil content per fruit fresh weight, even though the actual changes in the absolute amount of oil in the fruit are negligible. Figure 2A demonstrates a certain degree of dependence of oil content on a fresh weight basis on the fruit water content in 'Barnea' fruit samples collected from individual trees in Israel at harvest during the 2011 and 2012 seasons. Plotted against 

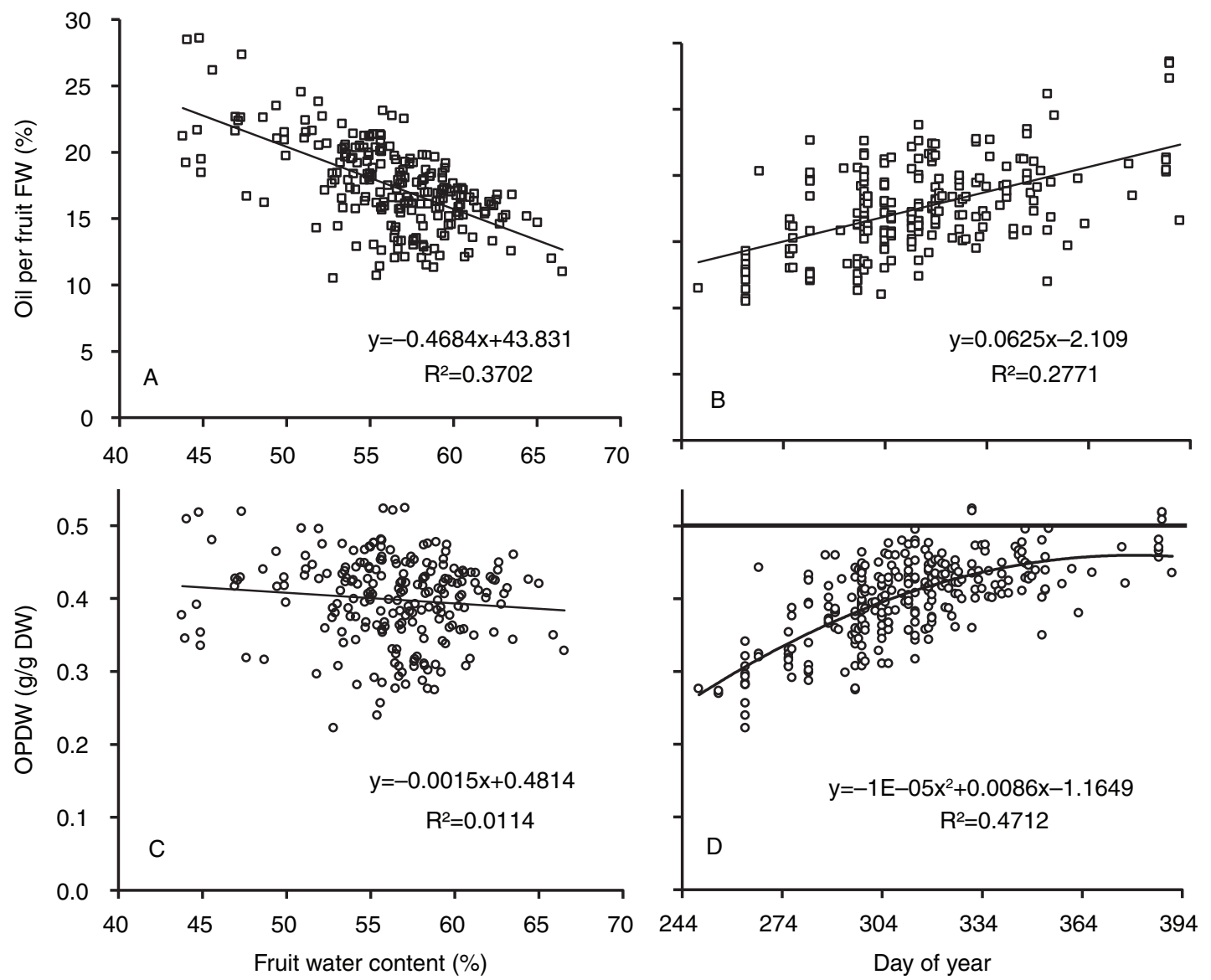

FIGURE 2. Relationships between oil content per fruit fresh weight (A) or per fruit dry weight (OPDW; C) and fruit water content, and the development of oil content per fruit fresh (B) or dry (D) weight during the harvest season. Data represent fruit samples harvested from August 2011 to January 2012 from individual 'Barnea' trees scattered among 25 orchards in Israel. A horizontal red line indicates the OPDW threshold of $0.5 \mathrm{~g} / \mathrm{g}$ DW.

a time scale (Figure 2B), the same data indicate a steady increase in fruit oil content during the fruit maturation season. Nevertheless, this relationship seems to have rather weak predictability.

A simple calculation step yields the paste's dry matter (100-WC) content. Thus, the paste oil content may be calculated per fruit dry weight (OPDW), needing no further laboratory work. Unlike the changes in fruit water content (Figure 2C), OPDW displays significantly reduced variability, obtaining a straightforward parameter of fruit oil content. When plotted against time of fruit maturation, OPDW provides a steady indication of fruit oil content (Figure 2D), as compared to that of the respective oil content per fresh weight (Figure 2B).

The FRI, or maturity index, has been widely adopted by the olive oil industry as a suitable marker for the correct selection of harvesting time (Uceda and Frias, 1975). The method is based on the gradual accumulation of anthocyanin in the olive fruit during the ripening process (Maestro and Vázquez, 1976), when oil is also produced and accumulated. However, the two metabolic processes are not necessarily linked, and Figure 3 shows some frequent exceptions. First, within a cultivar, as clearly shown for 'Barnea', 'Picual', and 'Souri', fruit yield plays a significant role; under low-yield situations, maximum OPDW values are reached at very low FRI. Under high yields, however, FRI might progress considerably while oil accumulation is very small. This is in accordance with earlier findings (Lavee and Wodner, 1991; Salvador et al., 2001; Dag et al., 2011), showing that fruit load has a major effect on oil accumulation in olives. Specific environmental conditions might also affect FRI and OPDW in different manners. Under the extremely warm and dry summer/autumn conditions typical of the Rift Valley (EinHanatziv), oil accumulated very slowly, remaining far below the $0.5 \mathrm{~g} / \mathrm{g}$ DW threshold, whereas FRI gradually increased beyond 5 ('Barnea') and 4 ('Picual') (Dag et al., 2013). In addition, FRI is strongly cultivar-dependent. In 'Leccino', for example, the fruit changes its external color long before the optimal harvest time (Figure 3), whereas in 'Coratina' and 'Askal', maximum oil accumulation is reached when most of the 

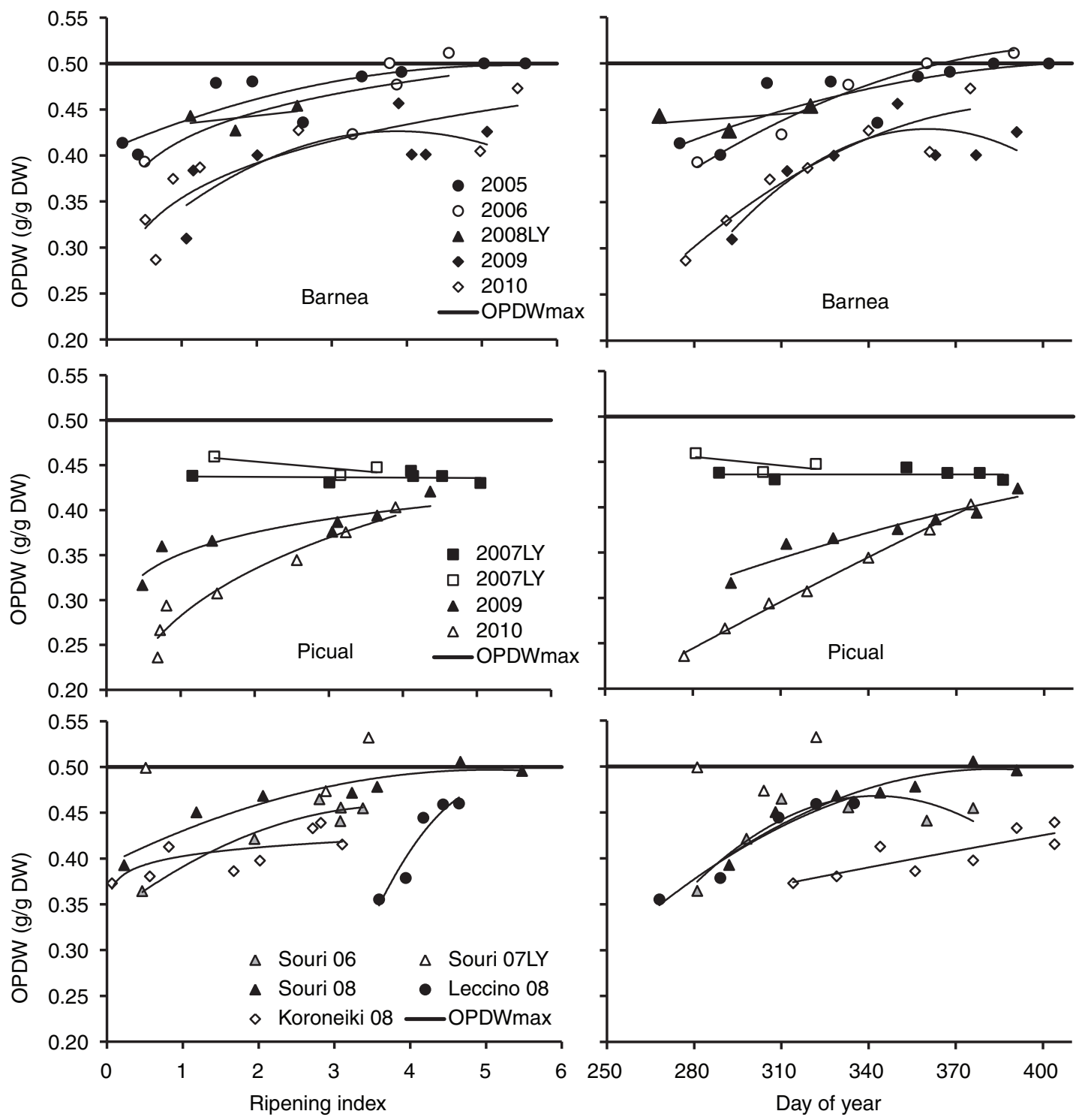

FIGURE 3. Relationships between OPDW and fruit ripening index (left) and OPDW progress throughout the harvesting season (right) in various olive cultivars and locations in the years 2005-2011. See more details in Table 1. A horizontal red line indicates the OPDW threshold of $0.5 \mathrm{~g} / \mathrm{g}$ DW. LY indicates low yield. Data are the means of fruit samples from five trees.

fruit is still green (data not shown). Thus, although suitable for most cultivars to vaguely recognize the approaching maturity of the developing yield, an indirect criterion such as FRI cannot determine the precise point in time at which maximum oil yield has been reached. Moreover, FRI cannot give the grower a quantitative assessment of the oil quality. Cherubini et al. (2009) proposed the fruit sugar concentration as an index for olive ripening and some quality aspects. Fruit sugar content can be measured easily and quite precisely using a portable refractometer (Migliorini et al., 2011). However, fruit sugar concentration is also temperature sensitive and therefore has low ability to predict harvest timing (Cherubini et al., 2009). The rapidly expanding sector of intensified cultivation in the global olive oil industry demands reliable new indicators for an educated selection of harvest timing.

Throughout the substantial body of data presented here, OPDW seldom peaked above $0.5 \mathrm{~g} / \mathrm{g}$ DW, assigning a saturation curve for the process of oil accumulation in the olive fruit with a ceiling at about this level. The notion of oil accumulation in olive fruits being restricted to a certain threshold, which actually represents the potential oil yield, is well established in the literature (Lavee and Wodner, 1991; Garcia and Mancha, 1992). Furthermore, the literature is rich with reports signifying a threshold 
of about $0.5 \mathrm{~g} / \mathrm{g}$ DW for many oil olive cultivars (Beltran et al., 2004; Mailer et al., 2007; Trentacoste et al., 2010; Bakhouche et al., 2014; Rondanini et al., 2014). It is worth noting that higher OPDW values usually relate to oil content in the fruit pulp only (Lavee and Wodner, 1991), and not in the olive paste. Nevertheless, to the best of our knowledge, this is the first attempt to use OPDW as a predictive tool for the determination of optimal harvesting time.

As shown in Figures 2 and 3, the rate of oil accumulation in olive fruit over time is largely affected by external (climatic and edaphic) conditions as well as internal (cultivar, yield) factors. Therefore, an efficient tool for predicting the optimal harvesting time should consider these relevant parameters, as demonstrated in the following case study (Figure 4). Fruit ripening, oil accumulation, and oil quality during fruit maturation in the 2012 season were monitored in a single 'Barnea' orchard, where trees were distinguished according to estimated fruit load. Here, again, FRI in low-yielding trees reached high values much earlier than in high-yielding ones. Oil content on a fresh weight basis, which differed significantly between the groups, displayed an interesting course; it increased dramatically toward 1 Nov but then declined continuously in fruit of the low-yielding trees. In the high-yielders, this parameter rose steadily until mid-November and then fluctuated thereafter. Obviously, fruit water content was the major factor affecting fruit oil content on a fresh weight basis; two significant events of heavy rainfall (8-12, and 22-26 Nov, $150 \mathrm{~mm}$ in total) brought about a sharp increase in the fruit water content, negating the pre-determined program to gradually reduce the water supply toward harvest. OPDW was significantly higher in the low-yielders early on (17 Oct) and increased steadily until mid-Nov, approaching the $0.5 \mathrm{~g} / \mathrm{g}$ threshold. Interestingly, in the high-yielding trees, OPDW remained at a low level $(<0.35(\mathrm{~g} / \mathrm{g}$ DW $))$ in late October, then surged to $0.42(\mathrm{~g} / \mathrm{g} \mathrm{DW})$ in November and remained stable thereafter. This course of OPDW suggests an important role of water stress and recovery in oil biosynthesis and accumulation, particularly in heavy-yielding trees, and reflects the difficulties of such trees to reach their oil yield potential. Noteworthy is the tendency of low-yielding 'Barnea' trees to already have undesirably high oil acidity values (Figure 4E) early in the season (Bustan et al., 2014), a phenomenon that requires special attention when the harvesting time is determined.

\subsection{The proposed OPDW method}

The most intensively cultivated oil olive orchards are held by large growers or cooperatives that own or have access to modern olive presses, where NIR measurements have been adopted. The availability
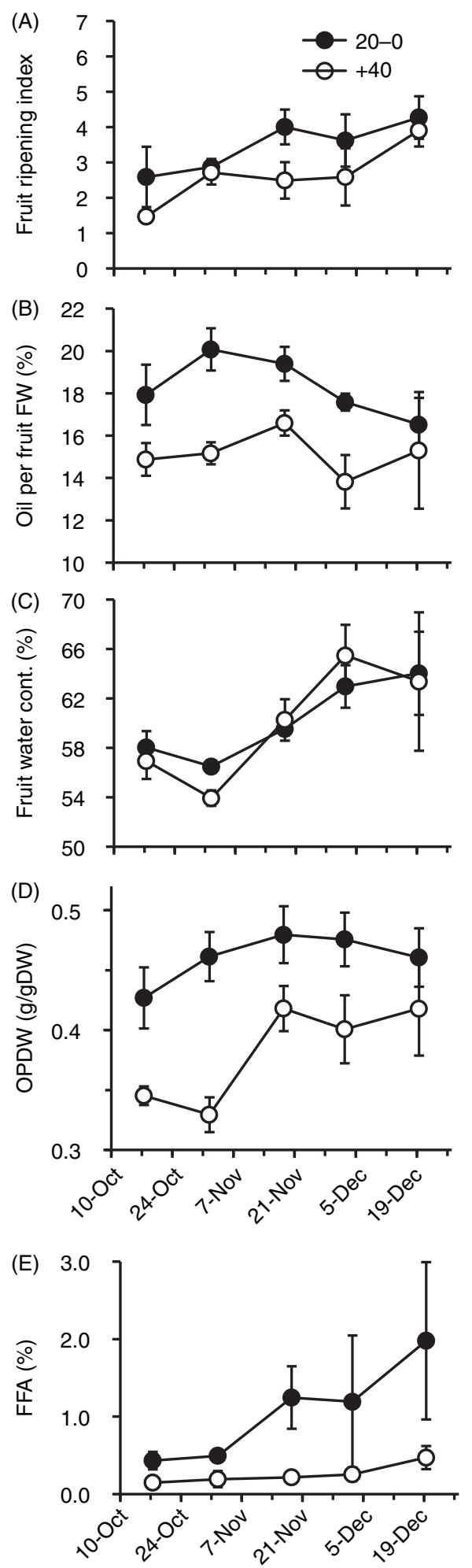

Figure 4. Effects of fruit load on the progress of fruit ripening season.(A), oil (B) and water (C) contents on a fresh weight (FW) basis, OPDW (D), and oil acidity

(FFA; E) throughout the 2012 harvest season in a single 'Barnea' orchard. Data are the means of fruit samples from 10 trees \pm SE. Low yield: $0-20 \mathrm{~kg} / \mathrm{tree}$; high yield: $>40 \mathrm{~kg} / \mathrm{tree}$. 
of this equipment and the ability to sample fruit systematically and timely are essential.

The proposed method is based on fruit sampling in the olive orchard and analysis in the laboratory. An accurate initial fruit sampling is crucial since oil accumulation in the fruit is strongly linked to the fruit load (Dag et al., 2013), which in turn is not uniform for all trees in a given plot. Hence, the collected fruit has to adequately represent the plot, e.g., if most of the trees in a given orchard/plot are carrying high yields, these will be the trees that are sampled, and vice-versa. We suggest that the best practice is to mark the sampled trees so that if successive sampling is required, they can always be taken from the same trees.

In the laboratory, the fruits are immediately crushed into a paste to determine water and oil contents, preferably by means of a calibrated NIR spectrometer, which is fast and easy. Once water and oil contents are determined, OPDW can be calculated.

Knowing that the maximum obtainable value of OPDW is ca. $0.5 \mathrm{~g} / \mathrm{g} \mathrm{DW}$ in most cases, the grower has immediate information as to how far the orchard is from exploiting its oil-accumulation potential and therefore, from harvest.

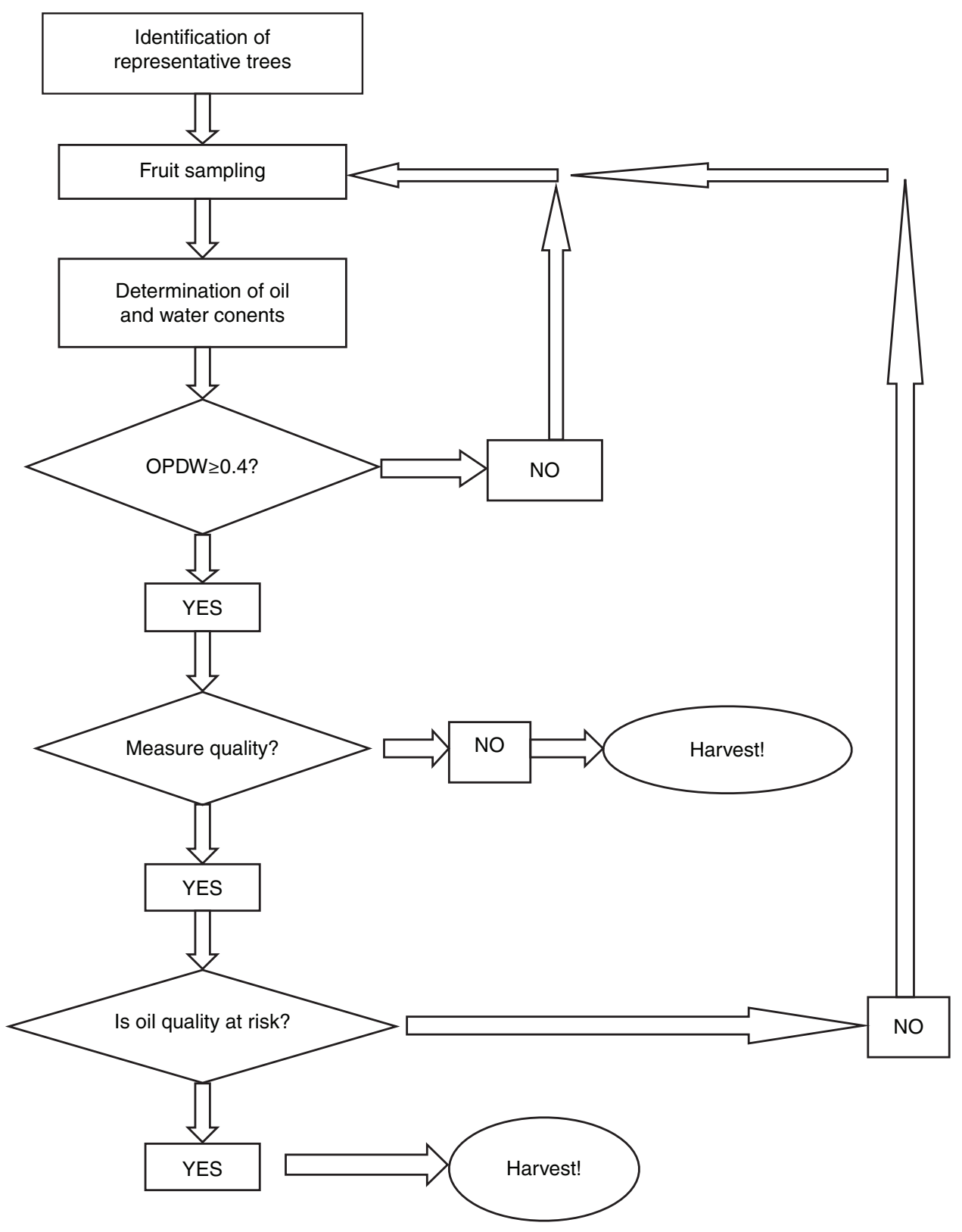

FIGURE 5. Flowchart of the proposed method for determining optimal harvesting time. The quality parameters and threshold values are to be determined by the grower or by other stakeholders. 
Oil quality is an important factor in the global olive oil trade, and makes a significant contribution to the grower's revenue. The first and most important parameter of oil quality is the oil's FFA content (oil acidity) but other parameters such as Peroxide value, $\mathrm{K}_{232}, \mathrm{~K}_{270}$ are included in the quality standards. In most cases, oil acidity increases with oil accumulation and fruit ripening (Dag et al., 2013). It is suggested that once OPDW reaches a value above $0.4 \mathrm{~g} / \mathrm{g} \mathrm{DW}(80 \%$ of the oil-accumulation potential), a cold extraction of the paste is performed to obtain the amount of oil required for a determination of FFA content and other desired quality parameters, including sensory properties. Once the grower has this information, a decision can be made about harvest timing, based on both parameters: oil quantity and desired oil quality. In many cases, it might be worth losing some oil to gain quality. In an upgraded version of the proposed method, fruit samples are collected at constant intervals from the orchard and OPDW and oil quality course are determined, thereby allowing "fine-tuning" of the decision about the optimal timing of the harvest.

We propose that an OPDW of $0.5 \mathrm{~g} / \mathrm{g} \mathrm{DW}$ be considered as a rough indicator, rather than a fixed goal. OPDW might be affected by factors such as cultivar, climatic conditions, pulp/pit ratio and more. OPDW may also be indicative of stress conditions (e.g., water shortage) in the orchard, as in the case of sluggish OPDW increment in the range below 0.45 .

Exceptions may occur. The recently introduced cultivar Askal can reach OPDW values of $0.6 \mathrm{~g} / \mathrm{g}$ DW or higher. The same holds true for the cultivar Souri under certain conditions; nevertheless, these are exceptions and most olive cultivars follow the OPDW value of $0.5 \mathrm{~g} / \mathrm{g}$ DW as a maximum.

A flowchart of the proposed method, including decision-making junctions for the grower, is demonstrated in Figure 5. This procedure has been successfully executed over the last three seasons in several large-scale orchards in Israel, whose growers used the resultant information to determine harvest timing. Logistic as well as weather events were also considered. The information obtained regarding fruit water content also served to manage an appropriate pre-harvest irrigation regime in an attempt to maintain optimal fruit water content at harvest $(50-52 \%)$, thereby retaining high extraction efficiency and avoiding substantial loss in polyphenols at the olive mill.

\section{CONCLUSIONS}

OPDW is a solid and reliable indicator for actual fruit maturity in olives that is easily calculated from NIR spectrometric measurements. OPDW increases during the season but sooner or later, it reaches a ceiling threshold of about $0.5 \mathrm{~g} / \mathrm{gDW}$ in the fruit of most olive cultivars. Approaching this threshold is the best indicator for termination of oil accumulation and the consequent reduction in its quality. The rates of OPDW and FFA increments strongly depend on local variables such as climate, tree water status, fruit infestation and fruit load. Here we propose a fast and easy method to determine and monitor OPDW in a given orchard. This method was proven useful for a precise determination of harvest timing, particularly in intensively grown orchards, for optimal olive oil yield and quality.

\section{ACKNOWLEDGEMENTS}

This research was funded by the Chief Scientist of the Ministry of Agriculture, Israel.

\section{REFERENCES}

Armenta S, Moros J, Garrigues S, de la Guardia M. 2010. The use of near-infrared spectrometry in the olive oil industry. Crit. Rev. Food Sci. Nutr. 50, 567-582. http://dx.doi. org/10.1080/10408390802606790.

Bakhouche A, Lozano-Sánchez J, Bengana M, FernándezGutiérrez A, Segura-Carretero A. 2014. Time course of Algerian Azeradj extra-virgin olive oil quality during olive ripening. Eur. J. Lipid Sci. Tecnol. 117, 389-397. http:// dx.doi.org/10.1002/ejlt.201400197.

Beltrán G, del Río C, Sánchez S. 2004. Seasonal changes in olive fruit characteristics and oil accumulation during ripening process. J. Sci. Food Agric. 84, 1783-1790. http://dx.doi. org/10.1002/jsfa. 1887.

Ben-David E, Zipori I, Weissbein S, Kerem Z, Basheer L, Dag A. 2010. Optimization of the Abencor system to extract olive oil from irrigated orchards. Eur. J. Lipid Sci. Technol. 112, 1158-1165. http://dx.doi.org/10.1002/ejlt.201000056.

Bustan A, Kerem Z, Yermiyahu U, Ben-Gal A, Lichter A, Droby S, Zchori-Fein E, Orbach D, Zipori I, Dag A. 2014. Preharvest circumstances leading to elevated oil acidity in 'Barnea' olives. Sci. Hort. 176, 11-21. http://dx.doi.org/10.1016/j. scienta.2014.06.028.

Cayuela P.J.A, Maria Garcia J, Caliani N. 2009. NIR prediction of fruit moisture, free acidity and oil content in intact olives. Grasas Aceites, 60, 194-202. http://dx.doi.org/10.3989/ gya.097308.

Cherubini C, Migliorini M, Mugelli M, Viti P, Berti A, Cini E, Zanoni B. 2009. Towards a technological ripening index for olive oil fruits. J. Sci. Food Agric. 89, 671-682. http:// dx.doi.org/10.1002/jsfa.3499.

Dag A, Kerem Z, Yogev N, Zipori I, Lavee S, Ben-David E. 2011. Influence of time of harvest and maturity index on olive oil yield and quality. Sci. Hort. 127, 358-366. http:// dx.doi.org/10.1016/j.scienta.2010.11.008.

Dag A, Harlev G, Lavee S, Zipori I, Kerem Z. 2013. Optimizing olive harvest time under hot climatic conditions of Jordan Valley, Israel. Eur. J. Lipid. Sci. Technol. 116, 169-176. http://dx.doi.org/10.1002/ejlt.201300211.

García C, Perez PA, Martín JM. 2004. The economics of olive oil. In: Olive Growing ( $5^{\text {th }}$ edition, $1^{\text {st }}$ English edition, 2010). Eds. D. Barranco, R. Fernandez-Escobar, L. Rallo, RIRDC, NSW, Australia, pp. 711-755. ISBN: 84-8474-128-1.

García JM, Seller S, Pérez-Camino MC. 1996. Influence of fruit ripening on olive oil quality. J. Agric. Food Chem. 44, 3516-3520. http://dx.doi.org/10.1021/jf950585u.

García-Martos JM, Mancha M. 1992. Evolución de la biosíntesis de lípidos durante la maduración de las variedades de aceituna "Picual" y "Gordal". Grasas Aceites, 43, 277-280. http://dx.doi.org/10.3989/gya.1992.v43.i5.1140.

García-Sánchez A, Ramos-Martos N, Ballesteros E. 2005. Comparative study of various analytical techniques (NIR and NMR spectroscopies and Soxhlet extraction) for the determination of the fat and moisture content of 
olives and pomace obtained from Jaen (Spain). Grasas Aceites, 56, 220-227. http://dx.doi.org/10.3989/gya.2005. v56.i3.111.

Harwood LM, Moody CJ. 1989. Experimental organic chemistry: Principles and Practice (Illustrated ed.). WileyBlackwell. Pp. 122-125. ISBN 0-632-02017-2.

Lavee S, Wodner M. 1991. Factors affecting the nature of oil accumulation in fruit of olive (Olea europaea L.) cultivars. J. Hort. Sci. 66, 583-591.

Lavee S. 2010. Integrated mechanical, chemical and horticultural methodologies for harvesting of oil olives and the potential interaction with different growing systems - a general review. Adv. Hort. Sci. 24, 5-15. http://dx.doi.org/ $10.1400 / 132337$.

Maestro DR, Vázquez A. 1976. Colorantes antocianicos de las aceitunas manzanillas maduras. Grasas Aceites, 27, 237-243.

Mailer RJ, Ayton J, Conlan D. 2007. Influence of harvest timing on olive (Olea europaea L.) oil accumulation and fruit characteristics under Australian conditions. J. Food Agric. Environ. 5, 58-63.

Migliorini M, Cherubini C, Mugelli M, Gianni G, Trapani S, Zanoni B. 2011. Relationship between the oil and sugar content in olive fruits from Moraiolo and Leccino cultivars during ripening. Sci. Hort. 129, 919-921. http://dx.doi. org/10.1016/j.scienta.2011.05.023.

Naor A, Schneider D, Ben-Gal A, Zipori I, Dag A, Kerem Z, Birger R, Peres M, Gal Y. 2012. The effects of crop load and irrigation rate in the oil accumulation stage on oil yield and water relations of 'Koroneiki' olives. $h$. 31, 781-791. http://dx.doi.org/10.1007/s00271-012-0363-z.
Proietti P, Antognozzi E. 1996. Effect of irrigation on fruit quality of table olives (Olea europaea L.) cultivar 'Ascolana Tenera'. New Zealand J. Crop Hort. Sci. 24, 175-181. http://dx.doi. org/10.1080/01140671.1996.9513950.

Ravetti L, Robb S. 2010. Continuous mechanical harvesting in modern Australian olive growing systems. Adv. Hort. Sci. 24, 71-77. http://dx.doi.org/10.1400/132345.

Rondanini DP, Castro DN, Searles PS, Rousseaux MC. 2014. Contrasting patterns of fatty acid composition and oil accumulation during fruit growth in several olive varieties and locations in a non-Mediterranean region. Eur. J. Agron. 52, 237-246. http://dx.doi.org/10.1016/j.eja.2013.09.002.

Salvador MD, Aranda F, Fregapane G. 2001. Influence of fruit ripening on Cornicabra virgin olive oil quality. A study of four successive crop seasons. Food Chem. 73, 45-53. http:// dx.doi.org/10.1016/S0308-8146(00)00276-4.

Tous J. 2011. Olive production systems and mechanization. Acta Hort. 924, 169-184. http://dx.doi.org/10.17660/ ActaHortic.2011.924.22.

Trentacoste ER, Puertas CM, Sadras VO. 2010. Effect of fruit load on yield components and dynamics of fruit growth and oil accumulation in olive (Olea europaea L.). Eur. J. Agron. 32, 249-254. http://dx.doi.org/10.1016/j.eja.2010.01.002.

Uceda M, Frías L. 1975. Épocas de recolección. Evolución del contenido graso del fruto y de la composición y calidad del aceite. In: Proceedings of II Seminario Oleícola International. Ed. IOOC, IOOC, Córdoba, Spain, pp.125-128.

Zion B, Bechar A, Regev R, Shamir N, Weissblum A, Zipori Y, Dag A. 2011. Mechanical harvest of olives-an operations study. Israel J. Plant Sci. 59, 71-84. http://dx.doi.org/ 10.1560/IJPS.59.1.71. 